\title{
O enigma Ernani Rosas
}

\author{
Augusto de Campos
}

Quando eu estudava a "harpa esquisita" de Pedro Kilkerry, consultando os indispensáveis estudos de Andrade Muricy - Panorama do movimento simbolista brasileiro e "Presença do simbolismo" (em A literatura do Brasil, coletânea crítica dirigida por Afrânio Coutinho) $)^{(1)}$ - chamaram-me a atenção os textos também dissonantes do catarinense Ernani Rosas, já tão afastados da comedida prática simbolista brasileira como próximos do pós-simbolismo radical dos portugueses Sá-Carneiro e Fernando Pessoa. Intrigou-me, ainda, a sucinta e misteriosa informação de que uma das plaquetes do autor - o Poema do ópio, de 1918 - era dedicada ao próprio Sá-Carneiro e a Luis de Montalvor, de quem Ernani Rosas fora amigo. Uma conjunção de personalidades que os poemas pareciam ratificar, mas que ficou reticente, sem maiores explicações.

No Panorama do movimento simbolista brasileiro figuram apenas 27 composições, tudo quanto Muricy pôde reunir das obras dispersas do poeta - o suficiente, porém, para marcar uma presença e uma linguagem incomuns em nosso meio. A par das afinidades com a poesia de Sá-Carneiro e de Montalvor, a aguda percepção de Muricy soube detectar nos textos de Ernani Rosas traços mallarmaicos ("Ernani Rosas levou a linhagem mallarmeana até uma indestrinçável interpenetração de hermetismo e non-sens") e mesmo surrealistas ("Precursor de certos aspectos do verbo supra-realista, é manifesto na sua obra um paralogismo, quase uma irracionalidade, como a duma bela planta tropical monstruosa. É o verbo encantatório em estado larval”).

Pouco pôde aduzir, no entanto, o sensível crítico do nosso simbolismo, sobre a vida de Ernani Rosas. Nascido em $1886^{(2)}$, no Desterro (hoje Florianópolis), filho de Oscar Rosas - simbolista de primeira hora e amigo pessoal de Cruz e Souza - o poeta, ainda jovem, transferira-se para o Rio de Janeiro, onde viveu obscuramente, exercendo profissões humildes, e morrera, esquecido, em Nova Iguaçu, em 1954. A pouco mais que isto se resumiriam as informações biográficas. Obras publicadas, apenas as plaquetes Certa lenda numa tarde (1917), Poema do opio (1918) e Silêncios (s/d). Muricy falava ainda de "copiosa produção inédita", embora apenas pequena parte dela houvesse sido incorporada à antologia do Panorama.

Desejoso de saber mais, tive oportunidade de conversar com o próprio Andrade $\mathrm{Mu}$ ricy sobre o poeta e sua obra. Segundo o crítico, que o conhecera pessoalmente e de suas mãos recebera alguns inéditos, tudo o mais se extraviara, guardado numa caixa ou mala com muitos escritos, que havia ficado com os parentes do poeta, após o seu falecimento. Nada mais se poderia fazer. Como recordação do nosso encontro e prêmio do meu interesse, Muricy presenteou-me com duas das chamadas "plaquetes" de Ernani Rosas - preciosas mas modestíssimas publicações, que nem capa possuíam: Certa lenda numa tarde - Parófrasis de Narciso por Rictos da Cruz (anotado a mão: Ernani Rosas filho de Oscar Rosas), oito folhas, sem data de edição, contendo os poemas "Sombra idílica", "As ninfas" e "Narciso", com datas esparsas que vão de 1913 a 1917; e Silêncios, apenas quatro folhas, sem data e sem o nome do autor.
AUGUSTO DE CAMPOS é poeta, tradutor de poesia e ensaísta. Seus livros mais recentes săo $\dot{A}$ margem da margem e Linguaviagem (ambos pela Editora Companhia das Letras).

1 Panorama do movimento simbolista brasileiro. Rio de Janeiro, Instituto Nacional do Livro, $1^{\mathrm{a}}$ ed., 1952; 2 ed., Brasília, idem, 1973. A literatura no Brasil. Rio de Janeiro, S. José, vol. III, T. 1, 1959.

2 Registrem-se, aqui, para melho contextualizaçáo do poeta, as datas de nascimento de alguns dos seus contemporâneos: 1885 - Kilkerry; 1888 - Pessoa; 1890 - Sá-Carneiro, a quem este estudo quer homenagea especialmente, em seu centenário.

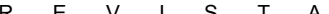


Foi, assim, com surpresa e com prazer, que recebi o volume das Poesias de Ernani Rosas, publicado em fins de 1989, em Florianópolis, pela Fundação Catarinense de Cultura (edição comemorativa do Centenário de Nascimento do Poeta), com organização, apresentação e notas de Iaponan Soares e Danila Carneiro da Cunha Luz Varella.

Por essa edição fica-se sabendo da existência de um acervo do poeta, recolhido, por iniciativa de Affonso Várzea, ao arquivo da Academia Catarinense de Letras. De acordo com os organizadores, os poemas reunidos na atual publicação "não representam um terço da obra de Ernani Rosas que ainda permanece inédita, em manuscrito, à espera de leitura cientificamente adequada capaz de elucidar com segurança as dificuldades de cada texto". Preferiram eles, diante de material de transcrição problemática, às vezes quase ilegível, optar por aquelas composições que se encontravam em forma definitiva, como as já divulgadas em folhetos ou jornais e aquelas que o autor deixara datilografadas para divulgação. De qualquer forma, é animadora a perspectiva de se conhecer melhor a poesia e os processos compositivos de Ernani Rosas que nos propicia esta relevante edição, consideravelmente ampliada, de sua obra.

Além dos poemas divulgados por Andrade Muricy, com leituras nem sempre coincidentes, e omitida apenas a quadra "Quando o Vento Sul..." (que, segundo Muricy, lhe fora ditada pelo autor), estas Poesias compreendem, ainda, outras corrposições avulsas (publicadas na imprensa ou datilografadas para publicação), t ma série de inéditos integrando o projeto de um livro organizadc pelo autor sob o título Ópio-poemas ilusionistas, e finalmente uma coletânea de mais cinco poemas inéditos manuscritos.

Em todo o conjunto há numerosas variantes, algumas vezes ocorrendo repetição de poemas com títulos diferentes - um material que suscita problemas de fixação de texto aqui e ali não inteiramente resolvidos, apesar do esforço dos organizadores, que listam as principais variantes e confrontos no capítulo "Considerações sobre esta edição". Assim, por exemplo, a transcrição do poema "Silêncios", que ficou a carecer de cotejo, não confere totalmente quer com a de Andrade Muricy, quer com a impressão original do poema: na terceira linha, a nova edição traz "colores" em vez de "colorís" (que deve prevalecer em função da métrica); na sétima, além de alterar-se a duvidosa palavra "euclasas" para a mais plausível "euclásias" (a forma correta seria "euclásios"), acentua-se "crisópraso", quando a rima exige "crisopraso"; na 35ª, está "agonizava" por "agoniza" (substituição mais uma vez desautorizada pela métrica); e na 47a, "Sou a boca do Sol-pôr!.", em lugar de "Sou a hora do Sol-pôr!". Como os autores se utilizam da $2^{\text {a }}$ edição do Panorama, de Muricy, agravam-se às vezes desnecessariamente os problemas de confronto: nessa edição, no poema "Narciso" (da plaquete Certa lenda numa tarde), aparece, certamente por erro de revisão, "desde" em lugar de "desce", como está, de forma correta, na $1^{\text {a }}$ edição. Já em "As ninfas", do mesmo livro, atribuem os organizadores ao autor a expressão "Sonhos do sol poente", cotejando-a com "Sonho do poente", que assim está em Muricy e no original impresso, sem esclarecer se a alteração foi feita pelo próprio punho de Ernani Rosas. Alguns erros de revisão, infelizmente comuns nas ediçōes brasileiras (jamais consegui que imprimissem "aromoso" $\mathrm{e}$ não "amoroso" no poema "Harpa esquisita" de Kilkerry...), complicam ainda mais a ecdótica: na comparação do poema "Salomé III" com a versão de Andrade Muricy ("Depois de te sonhar"), à pág. 26, aparece "chegando Espelhos" em vez de "cegando Espelhos" e "Som de Alardes" em lugar de "Som de Alarde" (que a rima impõe) como está na pág. 78. Restaria assinalar, ainda nesse caso, que a variante "raios d'Astros", por "raios d'Astro" é inaceitável (será lapso de escrita ou de cópia), pois quebra o decassílabo, dando-lhe uma sílaba a mais, erro não presumível em tão bom versejador como é Ernani Rosas. $O$ mesmo se diga em relação a algumas alterações, que não podem ser acolhidas, por danificarem a métrica: é o caso do "para" que substituiu a forma contraída "pra" na linha "Pra mim, tudo num Luar se estagnou", imprescindível para que a última sílaba de "luar" ocupe, como deve, a sexta sílaba. A métrica e a rima são elementos definidores no estabelecimento dos textos poéticos; não podem ser relegados.

Não obstante esses pequenos percalços, a nova edição é rica e generosa na revelação de textos inéditos, bem como na acoplagem de variantes. E além do mais, oferece, nos primeiros capítulos (pp. 9 a 19), diversas informações adicionais sobre a biografia de Ernani Rosas, até aqui tão escassamente delineada. Ficam-se conhecendo maiores detalhes sobre a sua presença no Rio de Janeiro, a sua atividade jornalística, a sua amizade e correspondência com Ronald de Carvalho (que, numa carta, o chama afetuosamente de "meu caro e apenumbrado irmão das cousas silentes, dos gatos, do aroma e da morte") e com o poeta português Luis de Montalvor. Quanto a este, cabe registrar a 
carta em que convida Rosas a colaborar na revista Orfeu, "este sonho enorme que vamos realizar e que tu tomarás parte a seu tempo", e da qual consta ainda esta curiosa advertência: "Trata de arranjar coisas tuas, mas com jutzo e unidade, coisas absolutas e necessárias para a orientação de Orfeu. Dá a Ronald o que fizeres! Porque tu sabes, além do seu grande talento ele tem mais juízo do que tu, pois ele é o talento gerador da moratória e dos câmbios invertidos..." Fornecem-nos, também, os organizadores alguns dados sobre as privações do poeta, que começam com o falecimento do pai, em 1925, e sobre os seus últimos tempos, época em que vivia num humilde sítio nos arredores de Nova Iguaçu, onde o foi encontrar, "magríssimo e espigado, como asceta hindu", o escritor Affonso Várzea. Em princípios de 1955 - esclarece-se - e não em 1954 como supunha Muricy, viria ele a falecer, de síncope cardíaca, em extrema pobreza.

No que tange às ligações entre Ernani Rosas e os poetas de Orfeu, estas informações complementam as que encontramos no livro $O$ modernismo brasileiro e o modernismo português - Subsidios para o seu estudo e para a história de suas relaçôes (Porto, 1986), de Arnaldo Saraiva, que, além de fixar definidamente o período em que Luis de Montalvor esteve no Brasil (de dezembro de 1912 a fins de 1914 ou ao início de janeiro de 1915), contém referências e documentos sobre o contato de Ernani Rosas com o poeta português: através das pesquisas de A. Saraiva verificamos que Ernani Rosas assistiu a conferências de Montalvor, em 1913, e que Ronald de Carvalho, em carta de março de 1915, prometera enviar ao amigo português, já em Lisboa, destinados à revista Orfeu, versos de alguns brasileiros, entre os quais Ernani Rosas.

Não há dúvida quanto à influência da poesia de Sá-Carneiro sobre a de Ernani Rosas. Primeiramente assinalada por Muricy, e também sublinhada por mim em ReVisão de Kilkerry (3), tal influência é reafirmada por Saraiva, que aventura a hipótese de sua extensão a Ronald de Carvalho (como também sugerira Muricy) e aos menos conhecidos Carlos Maul e Eduardo Guimarães. Em nenhum destes casos, porém, essa influência - se é que ocorreu - assume a relevância que assumiu na poesia de Ernani Rosas; aqui, não foram apenas temas e motivos - como o de Salomé, já presente em outros simbolistas como Eugênio de Castro, homenageado por Ernani Rosas com a dedicatória do poema "Narciso" -, mas a própria linguagem, no seu arrevesamento sintático, nos seus neologismos e formações vocabulares, que foi afetada, distanciando o poeta das convenções parnaso-simbolistas em que se moviam os demais brasileiros citados.

Ao publicar, em 1965, o artigo "Kilkerry: palavras-chave"(4), em que abordava o tema das ligações entre a poesia de Sá-Carneiro e a de Rosas, desconhecia eu o estudo que Cleonice Berardineli só divulgara na revista portuguesa Coloquio no 12 (Lisboa, fevereiro de 1961), e que, através da referência de Saraiva, vou descobrir agora, reproduzido em Estudos de literatura portuguesa (Lisboa, Imprensa Nacional - Casa da Moeda, 1985) sob o título "Ernani Rosas e Sá-Carneiro" (pp. 203-11). Nas poucas páginas desse lúcido trabalho evidenciam-se, pelo cotejo dos versos entre os dois poetas, afinidades e, mais do que isso, as ressonâncias do idioleto sá-carneiriano na poesia do brasileiro - patentes, por exemplo, na freqüência do adjetivo "ruivo" ("o meu ruivo destino às mãos da lenda enleio", “te arruivam de topázio os sonhos de ametista"), utilizado em versos que Cleonice Berardineli filia aos do poema "Certa Voz na noite, ruivamente...", do autor de Indícios de oiro, observando que, com este sentido, tal adjetivo só é encontrável em outro simbolista brasileiro, precisamente Pedro Kilkerry ("Sombras de voz hei no ouvido/ - De amores ruivos, protervos -/ Um pó vibrante de nervos.")(5); e flagrantes, tambêm, em construções verbais como "Cismo singrar-me lírio nessas tranças...", ou em compostos como "opio-indolente"; ou ainda em ideações temáticas e vocabulário diretamente hauridos no poeta português, como é o caso dos versos: "E a alma que anseia, se retarde, / no olhar do Além em nostalgia..." ("Elegia", de Poema do opio, 1918), certamente inspirados na linha “a minh'alma nostálgica de além..." do poema "Partida" (1913), de Dispersão.

Mais do que afinidade, houve portanto influência. O que não significa demérito, antes qualidade e discernimento, já que as ousadias da linguagem poética de Mário de SáCarneiro não tinham paralelo entre nós (se ressalvarmos a poesia de Pedro Kilkerry, mal conhecida e apreciada em seu próprio meio, a Bahia). Tal influência, de resto, se afigura plausível, pelo fato de Montalvor ter sido o maior divulgador da poesia de SáCarneiro no Brasil. Segundo Arnaldo Saraiva, diversas das conferências de Montalvor tinham por objeto a nova poesia de Portugal. E Saraiva nos fornece ainda outras informaçōes relevantes. Em carta de dezembro de 1913, Sá-Carneiro enviava a Montalvor exemplares de $\boldsymbol{A}$ confissão de Lúcio e Dispersão para serem distribuídos a intelectuais e

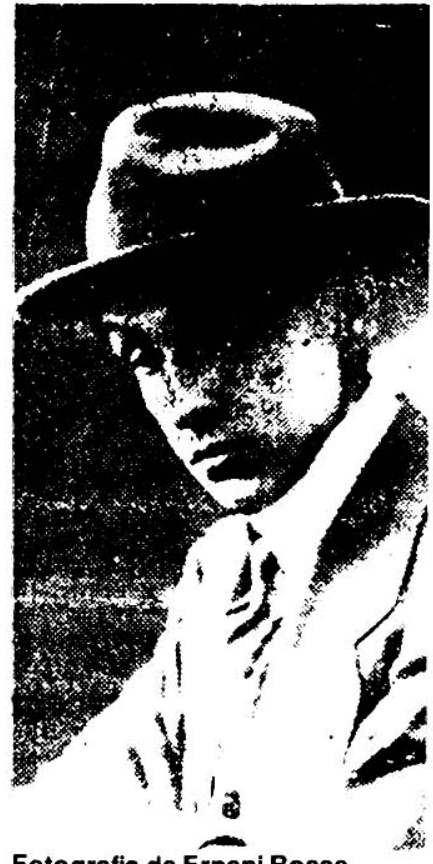

Fotografia de Ernani Rosas extraida de um recorte de jornal (estampada na quarta capa da edição Poesias, 1989, organizada por laponan Soares e Danila Carneiro da Cunha Varella)

3 ReVisăo de Kilkerry, Sáo Paulo, Fundo Estadual de Cultura, 1971 (2 ediçấo, ampliada, Săo Paulo, Brasiliense, 1985).

4 No "Suplemento Literário" de O Estado de S. Paulo, de 31/7/1965. Incluido como capitulo em ReVisăo de Kilkerry.

5 A nova ediçăo das Poesias de Ernan Rosas divulga na seçáo de Inéditos, "Ópio - poemas ilusionistas", entre textos que os autores supoem "datilografados de 1912 a 1914", o soneto "Choupos da tarde", datado de 1907. onde so encontra", da onde se encontra a linha "A vida Sol, que finda ruivamente...". Se data for correta, a influencia, no caso, se tempera com os naturais pendores da linguagem em formaçáo do poeta brasileiro. 
jornalistas do Rio de Janeiro. A Milton de Aguiar, um outro amigo - este, brasileiro - o poeta remetera os autógrafos dos sonetos "Salomé,, datado de 2 de novembro de 1913, e "Certa vez na noite, ruivamente", de 31 de janeiro de 1914, os quais viriam a integrar o volume póstumo Indícios de oiro. Dois poemas do livro Dispersão - "Vontade de dormir" e "Escavação" - foram publicados, respectivamente, nas revistas FonFon! (21/1/14) e Careta (20/6/14). A difusão dos poemas de Sá-Carneiro entre os intelectuais do círculo brasileiro de Montalvor resolveria, assim, o enigma da homenagem de Ernani Rosas em Poema do ópio, na já mencionada dedicatória (que não deveria ter faltado nesta nova edição): "aos irmãos de Salome: L. de Montalvor, R. de Carvalho e M. de Sá-Carneiro". Ademais, em versos como "Sol-posto ungindo o mar. Incensos d'Oiro" ("Elegia da quimera"), não deixaria Luis de Montalvor de influenciar o poeta brasileiro - conforme anota Saraiva - embora possivelmente fosse o próprio Montalvor influenciado por Sá-Carneiro.

Só muitos anos depois, na década de 40, quando as Edições Ática publicam as Poesias de Sá-Carneiro (1946), a sua linguagem renovadora voltaria a repercutir entre nós, na obra nascente de alguns dos então denominados "novíssimos", marcadamente no livro Poemas, de Cyro Pimentel, editado pelo Clube de Poesia, em São Paulo, em 1948. Equivocadamente vinculada, por uma crítica superficial, à "geração de 45 ", a obra de Cyro constituiu um caso único de poesia moderna pós-simbolista, dissonante e abstrata, ainda mal compreendido e avaliado entre nós. Nele, como ocorrera com Ernani Rosas, a influência de Sá-Carneiro não foi despersonalizadora; assimilada e retrabalhada com novos elementos, resultou em criações pessoais e autônomas. "Crianças-espelhos", "distância-saudade", "amores-noivos", "corpo cítiso", "corpo-arbusto", "mãos-anélitas", "Asas-Quiálteras" - inéditos conglomerados de palavras cunhados por Cyro Pimentel sob o incentivo das inovações do poeta português - eram um choque de renovação em nossa linguagem poética. Por outro lado, mesmo as marcas-patentes do idioleto sá-carneiriano, como o sintagma "'nostálgico de além"(6) e os desdobramentos de personalidade - a sua característica outridade - ganham em Cyro um toque de abstratização, uma refração lingüística peculiares, além de um ritmo próprio:
"Colunas centrais impedem o vôo icário,
De um incontido amor, às paragens solares:
$E$ inoculado de azul o ser volta
E é um céu
Nostálgico de além, saudoso de outro!"

O anacronismo e a excentricidade da poesia inicial de Cyro Pimentel, que impedem que seja inclú́da, quer na "geração de 45" quer nas tendências construtivistas de sua própria geração, dão-lhe contornos sui generis. Esses poemas serão talvez melhor compreendidos, dialeticamente, como uma reserva de potencialidades experimentais simbolistas. Colocadas entre parênteses pela urgência da revolução primitivo-coloquial do nosso modernismo, virão a ser recuperadas, em vários graus, na década de 50, justificando, em termos nacionais, as "re-visões" de Sousândrade e de Kilkerry (como a de Ernani Rosas), estes últimos como ápices radicais da segunda fase do simbolismo, colhidos no levantamento crítico operado por Muricy. De qualquer modo, considerações de ordem estético-evolutiva não devem obstar o reconhecimento dos resultados poéticos, e é preciso dizer que Poemas de Cyro Pimentel é um dos mais belos livros de poesia da minha geração, com achados inesquecíveis. Cito ao acaso: "Ah! o lento corpo! Rio sem destino para o mar"; "Deformei a vida para melhor me situar retângulo"; "Ouço as árvores executando trombetas"; "Quero tua ausência para mais me sentir ausente"; "A cidade dos Girassóis, o cemitério das cidades construídas"; "- Vida, Asa - Espectro - diluí-me na solidão dos céus,/ Ilhas sem mim"; "Passamos ao Além sombreados de Asas-Quiálteras, / Habitantes de esferas sem pauta, olhos sem pátria"; "Eu caminhante, sou a imaginação de mim"; "Áleas de rosas olham-se para o último sonho"; "Sê, fonte, apenas um desejo".

Notas dissonantes como essas foram feridas por um Kilkerry, quase sozinho, em sua "Harpa esquisita" (1909): "Pairas... Em frente, o mar, polvos de luz - estrelas... (...) E chamas a onda: 'irmã'. E em fósforo incendeia / Na praia a onda do mar, ri com dentes de espuma. (...) E és náufrago de ti, a harpa caída, agora". E também pelo nosso Ernani Rosas, nos versos de 1913-18.

O diálogo que se estabelece entre a sua poesia e a de Sá-Carneiro, admitida a in-

6 "A minh'alma nostálgica de além" ("Partida", 1913, Dispersáo). 


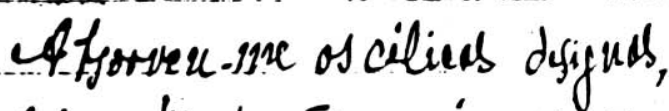

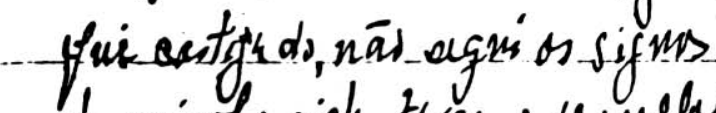

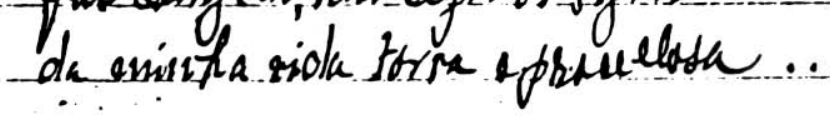

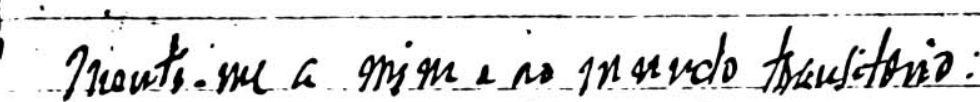

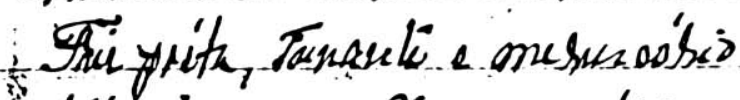
fate qle riute Sams mistriosa.

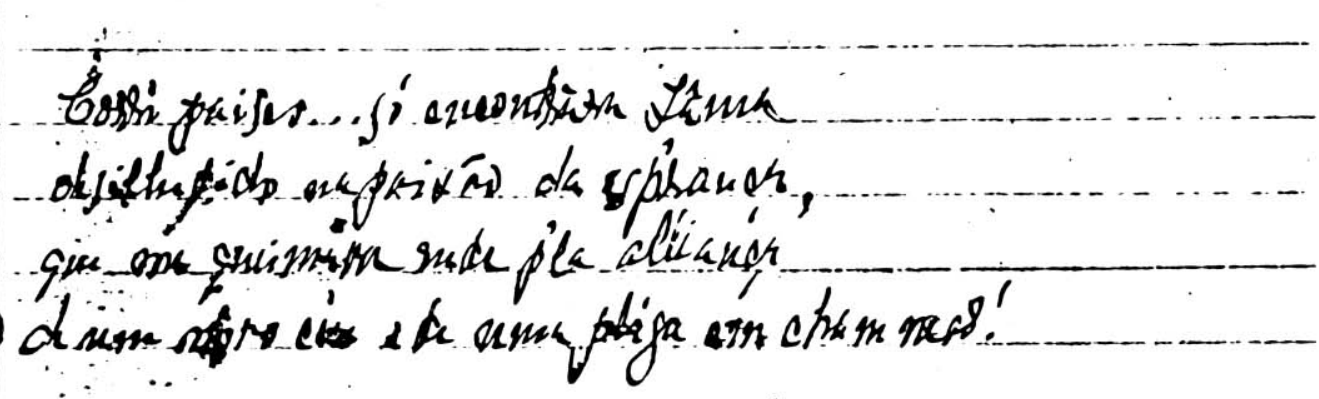

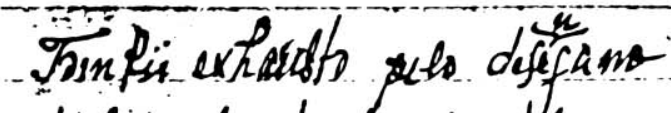

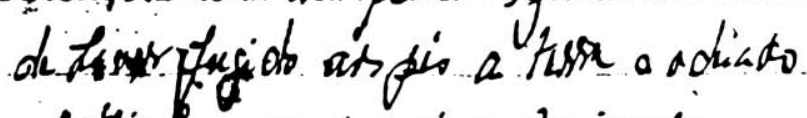

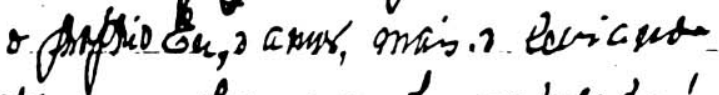

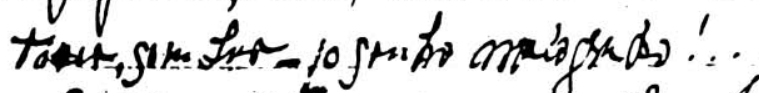

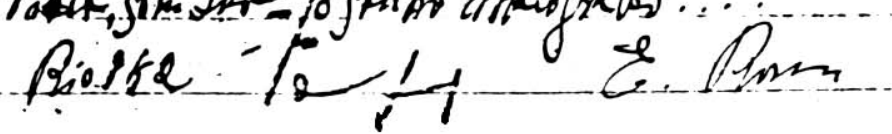

"Soneto"

Absorveu-me os célicos designos,

fui castigado, não segui os signos

da minha vida torva e procelosa...

Menti-me a mim e ao mundo transitório:

Fui poeta, tunante e merencório

Vate de linda Dama misteriosa!

Corri países... só encontrei Lama

desiludido na paixão da esp'rança,

que me queimava rude p'la aliança

de um novo céu e de uma plaga em chamas!

Tombei exausto pelo desengano

de haver fugido aos pés a terra e odiado

o próprio $\mathrm{Eu}$, o amor, mais o leviano

Viver, sem Lua - o sonho malogrado!...

Rio, 952
E. Rosas
Manuscrito inédito de Ernani Rosas, datado de 1952 (cópia cedida por laponan Soares para esta publicação). Junto, a transcrição de Augusto de Campos 
fluência deste, longe de desacreditá-lo, o situa em posição-chave, em termos de assimilação e reinvenção de inflexões novas, até então não adquiridas pelo simbolismo brasileiro, num momento em que as correntes de vanguarda européias já experimentavam liberdades lingüísticas e perquirições do inconsciente que só o futuro modernismo tornaria viáveis entre nós.

Já em sua primeira plaquete, Certa Lenda numa Tarde, subintitulada "Paráfrasis de Narciso" (fórmula que me sugere antes o vocábulo grego original que o plural, parecendo corresponder a "Paráfrase" e não "Paráfrases", como consta da nova edição), Ernani Rosas exibe a estranheza de sua linguagem, sem parâmetros no âmbito do simbolismo brasileiro. Embora dedicado a Eugênio de Castro, o texto de "Narciso" (1913), o mais antigo poema da coletânea, dialoga na verdade com Sá-Carneiro, em alexandrinos arrojados:

"Vislumbro esse jardim, onde a demência erra?

$$
\ldots \ldots \ldots \ldots \ldots \ldots \ldots \ldots \ldots \ldots \ldots \ldots \ldots \ldots \ldots
$$
como por mim se ausenta esse luar, que sinto?... vislumbro esse jardim em que órbita se encerra?

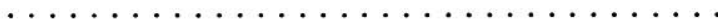
há mãos de musa a urdir a minha inquietação. $\ldots \ldots \ldots \ldots \ldots \ldots \ldots \ldots \ldots \ldots \ldots \ldots \ldots \ldots \ldots \ldots$ onde irá ter o seu suspiro de oiro aéreo?...

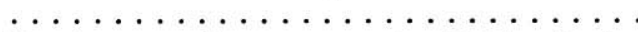
Eu sinto sepultar-me a noite d'além-fim! espelho-me a sonhar à sombra do jardim... $\ldots \ldots \ldots \ldots \ldots \ldots \ldots \ldots \ldots \ldots \ldots \ldots \ldots$ meu contemplo deliu-se lindo a oiro pálido... sou todo anel de Lua em linfa cristalina,

Outono a fenecer em meus gestos de seda,

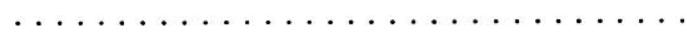
Perdi-me. O meu olhar era o mais lindo abismo, em que eu flor divaguei demência, num aroma... quebrou-se a gesto d'Alma... à beira dele cismo e sonho essa ilusão de ser olor, que assoma... através do meu ser - vago espelho sem-fim! aclaro-me a cismar no meu místico-Fim..."

Dalém-mar, a voz do narcísico poeta português:

"Numa ânsia de ser alguma cousa, Divago por mim mesmo a procurar. Desço-me todo, em vão, sem nada achar,"

(“Escavação”, 1913)

70 poema dramático "Salomé" (1896). de Eugenio de Castro, foi recentemente analisado entre nós por Álvaro Cardoso Gomes que, com propriedade, identifica "os estilemas da Salomé simbolista", ao mesmo tempo que assinala à limitaçôes do poema, que Ihe parece ser "frio, descritivo e, em muitas passagens, não passar de prosa rimada" (ver "Salome, starlet prosa imada" (ver "Salome, starlet simbolista in 0 poetico: magia e iluminaça. 1989 , pp. 51 a 88 ). Quanto à Herodias de Mallarmé, às complexidades de sua simbologia e de sua linguagem, remeto-me ao estudo "De Herodias à Jovem Parca", acompanhado de traduça do poema "Hbrodiade", em Linguaviagem (S. Paulo, Companhia das Letras, 1987)

8 "M'ilumino d'immenso!", diria Ungaretti em semelhante totalizaçăo imagética.

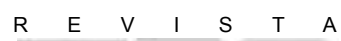

"Sinto os meus olhos a volver-se em espaço!

O bando das quimeras longe assoma...

$\ldots \ldots \ldots \ldots \ldots \ldots$

A cor já não é cor - é som e aroma!"”

("Partida", 1913)

“_ Ó pântanos de Mim - jardim estagnado!..."

("Apoteose", 1914)

“Num sonho de Íris morto a oiro e brasa,"

(“Distante melodia", 1914) 
"Há Oiro marchetado em mim, a pedras raras,

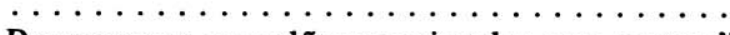

Percorro-me em salões sem janelas nem portas,"

("Taciturno", 1914)

Repare-se, nas linhas de Ernani Rosas - mais acentuadamente simbolistas - o domínio das sonoridades ("o meu suspiro de oiro aéreo"), a ousadia sintática ("eu flor divaguei demência"), o neologismo ("meu contemplo"), os compósitos inusuais ("além-fim", "místico-Fim").

Nos demais sonetos que compõem a série, a mesma estraneidade. No no I, de "Sombra idńlica", há uma "voz que se oira e arde". "Oirar-se" (e o desusado verbo "oirar" ou "ourar" tem duplicidade semântica, podendo significar "prover de ouro" ou "desvairar") é já levar ao paroxismo aquele "excesso de ouro" (M. S.-Carneiro) compartilhado pelos dois poetas. No no II, a bela linha "Inquietação da tarde sibilina", e a volta ao tema de Narciso: "Vi-me passar no Espelho d'hora antiga...", que reaparece no no III: "Perdi-me... toda uma ânsia me revela / sombra de Luz em corpo de olor vago," ("Perdi-me dentro de mim / Porque eu era labirinto", dirá o outro Narciso em "Dispersão", 1913). No no IV, uma nova constelação sonorista ("iriado lírio de luar nas Linfas...") e o retorno às sinestesias que confundem os sentidos: "Cismo singrar-me lírio nessas tranças". Nos dois sonetos que recebem o título de "As ninfas", a linha a destacar é a do primeiro: "Ó cabelos das ninfas - oiro a arder-Me!", que ecoam a "voz que se oira e arde" do inicial.

A "alma nostálgica de além", de Sá-Carneiro, ressoa em "Elegia", o primeiro texto de Poema do opio (1918): "E a Alma, que anseia, se retarde,/ no olhar do Além em nostalgia...". E o tema de Salomé, que irmana os dois poetas, se insinua no soneto "A luz que sobre si...", onde desponta uma ousadia: "O corpo, ópio-indolente, / oscila, desfalece ao meu desejo irreal...", capaz de dialogar com os "Enlevos de Ópio - Írisabandono..." do poeta português ("Anto", 1915). E aqui, a variante do poema "Salomé" (1914), de Rosas, dedicada a Ronald de Carvalho, trazida à luz pela nova edição, concorre com linhas significativas e até superiores em originalidade à versão conhecida: "Angelizada voz nessa Tarde de Lises / perdeu-se... em Outro-Azul espiritualizou-se! (contra: "Angelizada voz numa noite em que os lises / floriam pelo azul... na lenda humanizou-se,". Ou: "Sobre Ela a florir junto à Cisterna, Louca! / o disco singular da lua estagnou-se / em Raios que eram Alma, e um Lírio em sua Boca..." (contra: "Lúgubre agonizava à sombra da cisterna: / E uma voz de perdão, mais rude do que doce, / Parecia falar pela ilusão eterna!...").

A sombra de Salomé percorre os poemas restantes, mas de uma Salomé fragmentária e eterizada, que se afasta da Salomé mais corpórea e convencional de Eugênio de Castro (não obstante lhe deva sugestões léxicas e topoi imagéticos) e se avizinha da Salomé de Sá-Carneiro, já a meio caminho da Herodias de Mallarmé(7). No soneto "O meu ruivo destino às mãos da lenda enleio" é a própria Salomé que monologa: "Acordei como a luz piscinas num jardim". Em "Não serás tu, a sombra..." um cisne mallarmaico projeta na água a bizarria de "todo um zainfe lunar em névoa constelada" (zainfe = manto de Tanit, deusa cartaginesa). Já em "Quem és tu, loba...", a voz do Narciso-poeta volta a se imiscuir num verso que é um esplêndido poema dentro do poema, em duas palavras: "Inesperadamente, entardeci!"(8). Mas o soneto ainda nos reserva uma outra beleza em sua última linha: "Coluna envolta à vida dos teus dedos." No soneto "O sonho-interior" ressaltam os versos que compactam espelhamentos reflexivos: "Perdeu-se-me ao Sol-Por teu rastro amado" e "Velaram-se Sudários teus Espelhos..." (que poderia dialogar com o sá-carneiriano "Morreram-me meninos nos sentidos", de "O fantasma", 1916). O soneto seguinte, "Depois de te sonhar...", traz a linha "vesti teu Ser a raios d'Astro e Olvido", e o sintagma "Horas de Sonho-Asa", que remetem à dicção de SáCarneiro, trazendo à memória compósitos como "Horas-platina", ou "tempo-Asa", de "Apoteose" (1914); e no soneto "Outubro, o sol...", a linha "Anda um tecer de luz a oiro em seda!" poderia conversar com o verso "Num sonho de Íris morto a oiro e brasa,", de "Distante melodia" (1914). O último soneto dà seqüência, "À tarde o poente desfia...", heptassílabo, condensa admiravelmente as imagens em breves aglomerados paratáticos:

“Cintilos d'Astros, Poema! 
Diluir d'Opalas, Jardim...

De Salomé: o Diadema!"

"Contam que o teu olhar urde...", em versos heterométricos, é uma das mais marcantes composições dessa fase, embora se concentre mais descritiva e realisticamente na dança de Salomé, e, desse modo, se mostre algo tributária do poema dramático de Eugênio de Castro. Todavia, a rica elaboração de Ernani Rosas não deixa de se fazer presente, como neste trecho, em que as seqüências aliterativas em " $m$ " e " $n$ ", girando em torno da consoante labiodental " $t$ ", criam um clima sinestésico através de uma teia de atrações fonêmicas:

"Teimosa, oculta mão te impele para o crime, fascinas, fascinada...

És toda encantamento e tentação sublime...

Vens d'alma constelada...

Tudo te encanta e tenta em torno de teus pés...

Cavam-se abismos...

A própria tentação por ti é fascinada,

te arruivam de topázio os olhos de ametista..."

Nesse poema, e em alguns outros da série "saloméica" se evidenciam, também, os processos de reelaboração utilizados por Rosas relativamente às suas fontes ou matrizes estilísticas, no confronto com "Salomé" de Eugênio de Castro.

Vocábulos como "piscinas", "pedrarias", "repuxos", "crótalos", "sedas" e "alamedas" derivam do léxico de Eugênio de Castro para o poema de Ernani Rosas, porém rearranjados e compactados em notações abstratizantes:

\section{Eugênio de Castro}

"Salomé deita a comer aos peixes,

Que na piscina são relâmpagos de jóia."

Ernani Rosas

"Despertam do palácio os jardins e as piscinas..."

\section{Eugênio de Castro}

"Corre por toda ela um suor de pedrarias, Um murmúrio de cores."

"Os repuxos cantantes

Aclamam Salomé que entra no peristilo..."

\section{Ernani Rosas}

"Acorda a escuridão: como que desabrocham florentes, orquestrais as franças dos repuxos, como flores sensuais feitas de pedrarias..."

\section{Eugênio de Castro}

"Diz-lhe, agitando, à luz da lua adamantina, Seus crótalos de buxo, onde ardem cabuchões."

\section{Ernani Rosas}

"Como que a lassidão do ambiente se constela e os crótalos vibrando adejam em torno dela, parecem ter anseios..."

Mesmo onde é mais ostensivamente devedora de Eugênio de Castro, a linguagem de Rosas tende a divergir para regiões menos convencionais. É como se o olhar crítico do poeta brasileiro procedesse a uma releitura da Salomé do mestre português, selecionando-lhe os momentos e o léxico menos descritivos e aí operando uma filtragem, por deslocações e sínteses, no sentido de uma relação mais abstrata com o tema.

Assim, a linha em que o movimento da dança é definido por uma variação intra-rími-

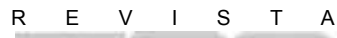

164 
ca em torno de terminais consoantes em "ança": "Como que adormecida ela avança a dançar”, que condena duas linhas separadas da descrição de Eugênio de Castro: “a infanta avança então, ao som dos burcelins..." e "Dir-se-ia que dança adormecida..." de mais morigeradas assonâncias.

Os versos finais da "Salomé" de Eugênio de Castro exemplificam ao mesmo tempo a aproximação e o contraste entre os dois poetas:

"Cantam, de Salomé no perfil de moeda,

Dourado p'la ambição, os olhos de ametista,

E junto do tetrarca a sua voz segreda:

- "!Dá-me a cabeça de João Batista!"

Treme o tetrarca, ouvindo tal:

- "Preferira dar-te

Toda a baixela, todo o meu tesouro...

Mas, breve, um gesto seu, um escravo negro parte,

Uma espada levando e um grande prato de ouro..."

Sob a leitura de Ernani Rosas, os sintagmas de Eugênio de Castro explodem fragmentariamente para pontos diversos dos poemas "saloméicos". O "prato de ouro" se fixa no final de "Contam que o teu olhar urde...", num contexto mais vago:

“Quase desfalecida

suplicam-lhe os anéis...

Ao som dos burcelins e crótalos, tentada,

Salomé traz às mãos egrégio prato de oiro!..."

onde veio parar, também, “o som dos burcelins” que já ouvíramos no verso de Eugênio de Castro "E a infanta avança então, ao som dos burcelins...". Mas os "olhos de ametista", aqui não assimilados, se introjetam nos versos iniciais "te arruivam de topázio os olhos de ametista," e o "perfil de moeda" engasta-se na quadra inicial de um dos sonetos da série:

"Depois de Te sonhar Mistério ido

e de seguir-Te e ouvir-Te em Hora leda, vesti teu Ser a raios d'Astro e Olvido, de Antiguidade o teu perfil de Moeda."

As palavras-rimas "seda" e "alameda" oferecem outro exemplo expressivo de apropriação criativa:

Eugênio de Castro

"Longe, na alameda,

Cantam pavões, à luz da lua merencória...

E Salomé, cerrando as pálpebras de seda,

Adormece a pensar na sua glória..."

Ernani Rosas

"Há rondas de faisões na soturna alameda..."

Aqui não há rima. Porém, o par "alameda/seda" comparece em vários dos sonetos "saloméicos" de Poema do ópio:

“Amara-me o bailado à lua na alameda

Do parque atravessando a transparente seda",

("O meu ruivo destino")

"na demência autunal duma Alameda...

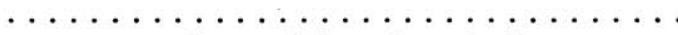

ante o cerrado teu Olhar de seda,"

("O sonho interior")

“Guardo um rumor de folhas na alameda 
Anda um tecer de luz a oiro em seda!"

"Fulgores de rubra seda

("Outubro, o sol")

$\mathrm{Na}$ dolência carmesim

Que vai do poente à alameda..."

(“À tarde o poente desfia...")

E em Silêncios, onde o tema de Salomé reaparece, mais decantado, numa elaboração abstratizante:
"Uma princesa descansa
à sombra de uma alameda:
todo longe é uma esperança
e a hora fenece em seda..."

Um último exemplo. O tríptico analógico "navio", "serpente", "borboleta", delineado por Eugênio de Castro para configurar os movimentos ondulantes da bailarina:

"Ninguém te vence, flor, nas danças voluptuosas!

Ora altiva, ora lânguida, ora inquieta,

Traçando no ar gestos macios como rosas,

És navio, serpente e borboleta!"

é desenvolvido por Ernani Rosas em sugestões imagísticas dispersas pelo texto, sem a rígida equivalência dos elementos comparativos:

"E ao som d'harpas ideais, de cítaras e lira

de profanos Poetas...

a tua silhueta rompe da escuridão,

como uma borboleta

quimérica e irreal...

tendo o corpo colmado a lúcido brocado,

traz lírios à cintura...

E os dedos a bater são ramos a brilhar..

São asas de falena ao sol a cintilar;

metálico florir em torno a dissonar -

Azul esplende a chama em carícias de serpe

que se enrosca em seu braço."

A imagem surpreendente que une diretamente os dedos a bater e os remos a brilhar contrasta com a descrição mais corriqueira no trecho correspondente da "Salome" de Eugênio de Castro:

"Radioso o véu, mais leve que um perfume,

Cinge-a, deixando ver sua nudez morena,

Dos seus dedos flameja o precioso lume,

E em cada mão traz uma pálida açucena."

Salomé está, ainda presente - conforme já acentuado - na plaquete Silêncios, onde Ernani Rosas (talvez possuído da mesma inquietação que levou Kilkerry aos derradeiros experimentos de "Longe do Céu, perto do Verde Mar" e "Ad Juvenis Diem") prossegue em sua exploração dos ritmos heterométricos e encontra uma linguagem mais pessoal. O poema começa com um alexandrino pregnante e original: "Ondulação da cor, teoria das horas". Dos dodecassílabos iniciais passa ao heptassflabo, para chegar, após algumas reminiscências de Eugênio de $\operatorname{Castro}^{(9)}$, à concisão destas estrofes lapidares, que rivalizam com o simbolismo avançado de "Horas ígneas" de Kilkerry:

9 As "euclasas e crisoprasos" têm algo das "cornamusas e crotalos" de "Ambientes", do poeta português.
"Iniciam-se de seda

uns idílios de prelúdio:

sonha o cisne de uma Leda
$\mathrm{R}$

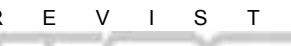

166
Setembro

Outubro

Novembro

1990 


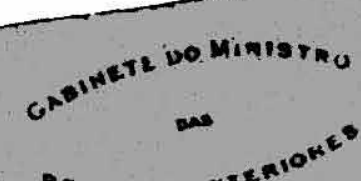

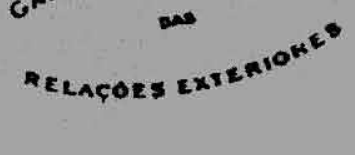

Mance de M CM XV

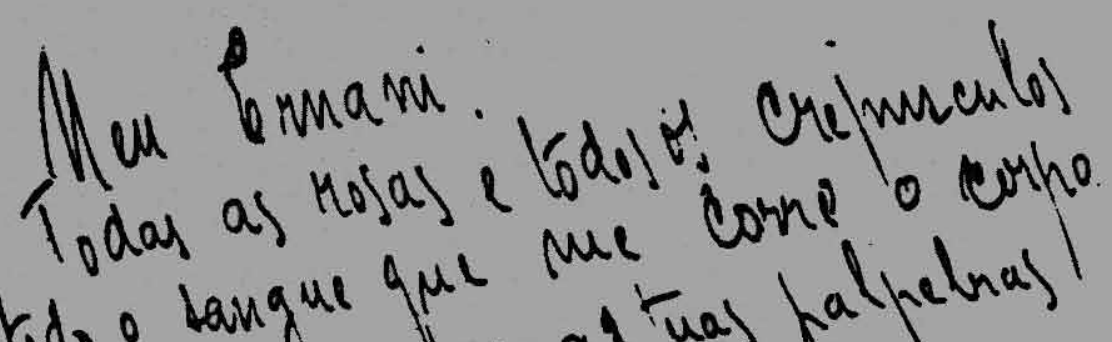
todo o tangue gue Me truas al actras raćo aqui beucterer at uas Nial ! de Muraseimeito hara a semana de Dehors de munalloma Rum, Más sei .

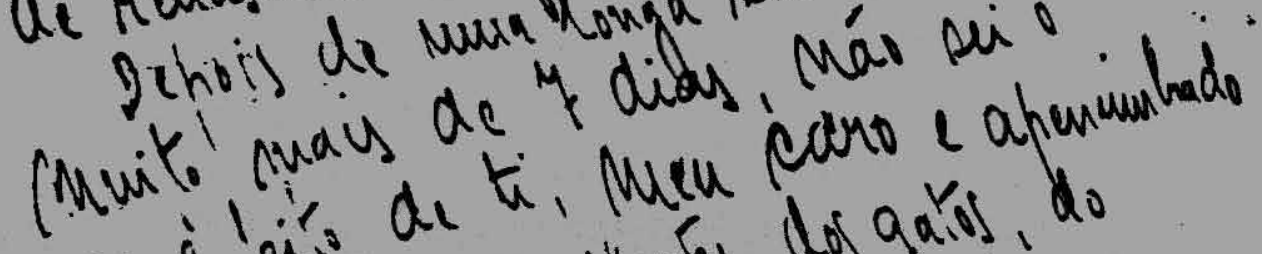

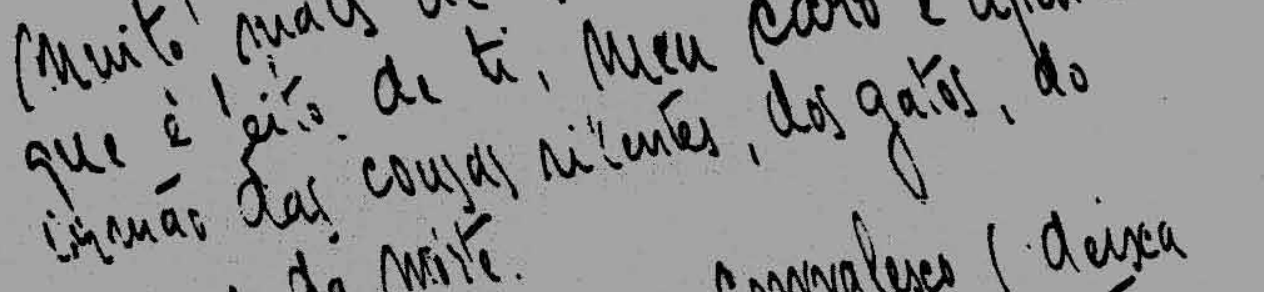
suma c da mití. pender 1 rucausto de minia

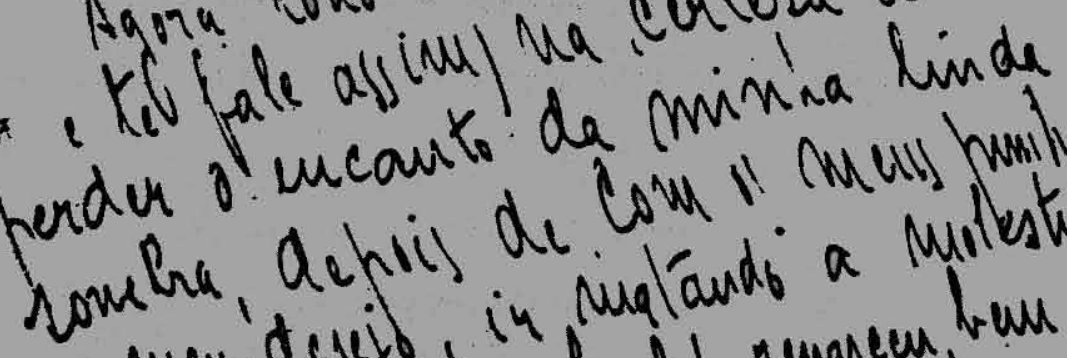

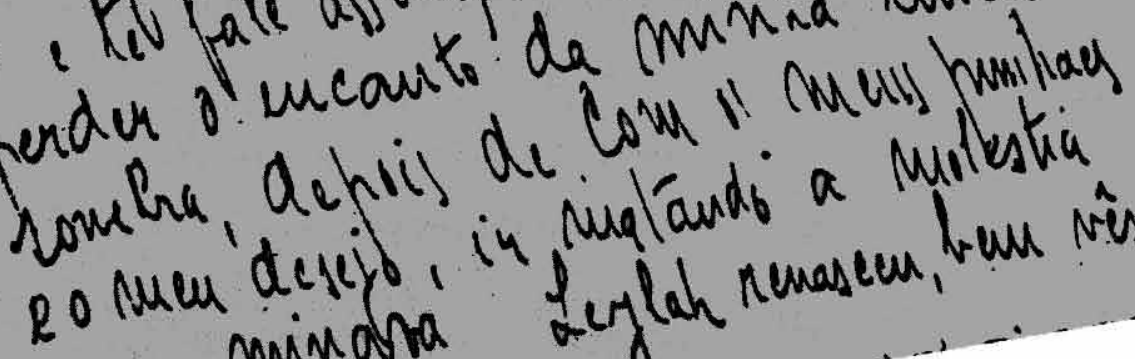
grae a minobra Leylah nemasem,

Trecho de carta de Ronald de Carvalho a Ernani Rosas, com data de 1915 (cópia cedida por publicacares para esta publicação)

Setembro

R $\quad E \quad V \quad I \quad S \quad T$

Outubro

1990

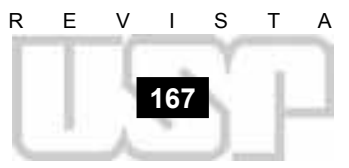


mais o sentido de um mudo!

\author{
Uma princesa descansa \\ à sombra de uma alameda: \\ todo longe é uma esperança \\ e a hora fenece em seda... \\ Pelas charnecas a Lua \\ constela de diamantes a vereda... \\ E a hora é Salomé sob esplausos de Luz."
}

\begin{abstract}
"Esplausos" - o enigmático neologismo, engastado no alexandrino que sintetiza o momento mágico ("a hora é Salomé") vai-se encontrar com outro - "noctiluzem" - no dodecassílabo "As cisternas, ao fundo noctiluzem luar...". Entre as linhas finais, mais um achado - o decassílabo "beijando a ara azul da hora, que ajardinas", onde reluz esta "ara azul da hora", decantação das "aras" de Mallarmé e Pessoa.

Ernani Rosas é um criador de esplêndidos versos, e os seus "avulsos", com poemas que vão de 1904 a 1947, mostram que o poeta manteve ao longo dos anos, com algumas recaŕdas simbolistas, a nova linguagem conquistada nos anos 13-14. Se, em alguns poemas mais antigos, como no soneto "Versos", de 1908 ("Ó capitosos, delirantes beijos!"'), denota influência de Cruz e Souza, já dois anos depois acusa certa dicção diferenciada: "Ó noites de Luar! Prenúncios d'Além vida...", ou "Transformação genial de fera em andorinha...". De 1912 é também a linha "Passeia, à luz cerâmica das Eras:" ("Misticismo do Outono"). De 1913: "Infância embalsamada num Sol-pôr:" ("Espiritualismo"). Do mesmo ano é o longo poema "Elogio dos Vitrais" - revelado pela nova edição -, que, como "Silêncios", principia com uma linha significativa: "Corpo de som e cor, forma velada" e cresce em abstrações e complexidades metafóricas:
\end{abstract}

"Como um vento de Morte e de segredo

Que passasse entre as folhas sem movê-las!..."

O Sol abrindo a Alma em forma d'Iris..."(10)

Ó pôr-do-Sol da Vida nos Olhares,

Olha! o Além é o eleito de Almas brancas...

Ó Tristeza infinita da Tristeza,

Astros! olhos sombrios do mistério!..."

Em 1918 rememora, já em plena dicção renovada pelo pós-simbolismo português:

"Volto a cismar, ao cais de onde parti...

- e do naufrágio a Lenda a recompô-la...

num poeta em que há anos perecei..."

versos que poderiam casar-se perfeitamente aos de Sá-Carneiro:

"Começam-me a lembrar anéis de jade

De certas mãos que um dia possur."

(“Apoteose", 1915)

Ainda em 1936, dirá, magnificamente, no soneto "Lúcifer":

“vivem mármores d’alma no poente!

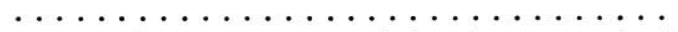

e o espelho em que me vi é tudo auroras!..."

"Quimera", de 1944, traz, ao lado de um bem simbolista "Mocho do tédio", a linha "da nossa astral, cruel decepção!...", que ecoa o distante "desdém Astral" do poema 
“Taciturno" (1914), de Sá-Carneiro. De um dos últimos sonetos de Ernani Rosas, datado de 1947, um verso relampagueia, fugindo ao convencional em que parece ter recaído a sua linguagem: "Passou metade-luz por noite escura,"(11).

Os outros avulsos, que formam o conjunto de inéditos reunidos na nova edição sob o título Ópio - poemas ilusionistas (textos datilografados, datados de 1907 a 1915) não alteram o quadro delineado, embora proporcionem, além de algumas variantes curiosas, momentos brilhantes em que Ernani Rosas mostra sua versatilidade estilística. Em linhas curtas, como:

\author{
“'Outono d'Oiro \\ o ar aloirece \\ ........... \\ tudo é vislumbre \\ duma hora d'Asas

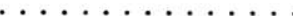 \\ perfume em ser-Me" \\ (“Canção d'alma”, 1916)
}

(o último verso merece cotejo com o de Sá-Carneiro - “Catedrais de ser-Eu por sobre o mar...", de "Distante melodia”, 1914). Em hexassílabos do porte de:

"A luz prende no chão

a Asa da folhagem:

Ó Almas que nos dão,

o Olor de si a aragem..."

("Fim do dia", 1913)

Ou em heptassílabos:

"Espalto (12) de sombra à escada

do sonho pra Alma tua...

é penumbra olorisada, que sobe do Outono à Lua!

Penumbra loira de sons"

$$
\text { (“Balada", 1915) }
$$

"Existo nas noites brancas, sou um sono no jazigo: tenho Saudade de Mim pela cisma, que te sigo!...",

("Balada d'ausência e da saudade”, 1916)

(“E, hoje, quando me sinto / É com saudades de mim.", está em “Dispersão”, 1913, de Sá-Carneiro). Ainda, em octossílabos:

"Correndo em horas hialinas a um luar de ânsias e de ais minha saudade - Turmalinas por ti em joias irreais."

(“Elegias do sol e da sombra”, 1916)

"saudoso adeus de roxo em ti espiritual violeta d'alma que a luz do dia não sorri"

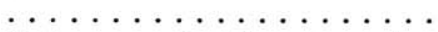

Quisera assim fixar-te a oiro

Ó minha azul melancolia

Amortalhada à nostalgia

vais a sangrar os pés d'aurora

num roxo Fim que o dia chora
10 Cf. Sá-Carneiro: "Ela chama-me em Iris. Nimba-se a perder-me" ("Salomé", 1913). "Num sonho de ĺris morto a oiro e brasa". ("Distante melodia", 1914).

11 A $1^{\mathrm{a}}$ ediçấo do Panorama do movimento simbolista brasileiro, de Muricy, estampa à p. 37 do vol. III, em precária impressão, uma versão manusc-ita deste poema, sob o titulo "Soneto", com ligeiras variantes (a II"Sch om questá IO-se: "Passou (a ) (Psou metaA minh citaçáo provém da $2^{a}$ ediçáo onde, sob o nome "Tísica", se transcreve outra versão, que veio a ser adotada pelos organizadores das Poesias. Além desse soneto, Muricy acrescentou os poemas "Trago de Hamleto a Dúvida ". "Quando o Vento Sul" "Para qu... "Quando o Vento Sul" "Para que Alma, o Esforço", que náo
figuraram na ediçăo anterior.

12 "Espalto" = tinta escura que os pintores aplicavam sobre o escarlate. A palavra forma com "euclasas" (euclásio = mineral que ocorre em forma de cristais prismáticos, às vezes usado como gema) e "esplausos" (?) um estranho tríptico de vocábulos raros ou inventados. no idioleto poético de Ernani Rosas.

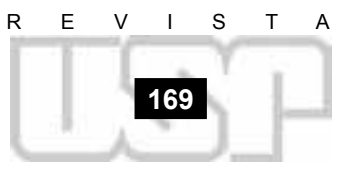


de Mim murmura a pedraria"

Ricos de achados, os decassílabos e dodecassílabos em que tantas vezes se expressaria:

“A vida - Sol, que finda ruivamente..."

("Choupos da tarde", 1907)

"Toda velha Tristeza duma luz, no Outono, envelheceu de azul o meu quarto deserto"

$$
\text { (“Tristeza da lâmpada", 1915) }
$$

"Sonolência da cor! Cai indolência verde.

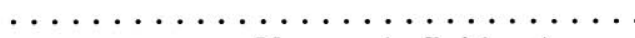

Vespas de fluidas Asas,

que se agitam no ar: Linfa a filtrar luares!"

("Melancolia", 1915)

"ressurjo. Amo o luar do meu Não-Ser..."

("Insônia à lâmpada", 1914)

(em Mário de Sá-Carneiro encontramos: "Há vislumbres de não-ser:" - "Rodopio", 1913)

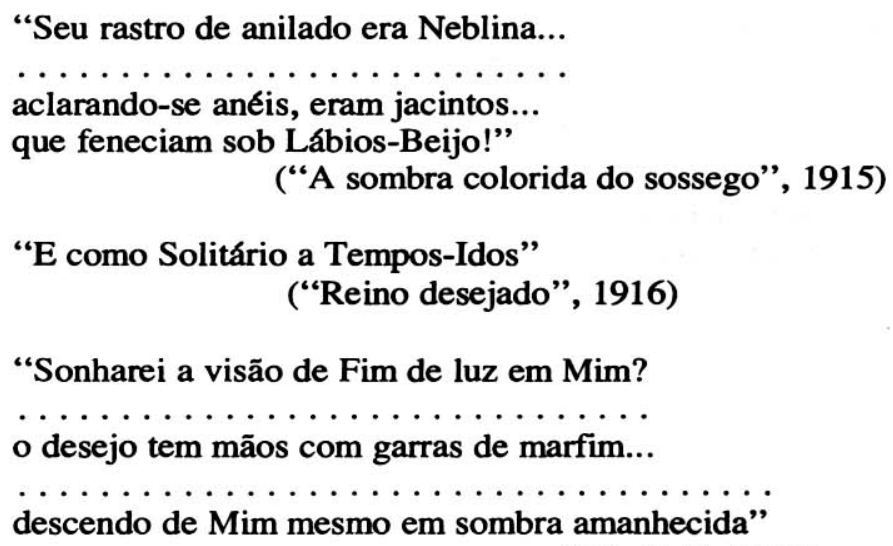

("Exílio", 1916)

(esta última linha sugerindo comparação com o "Rolo de mim por uma escada abaixo", de "Manucure", 1915, de Sá-Carneiro).

"Irrealizei-me Luz de teus baços Vislumbres morrente d'Oiro à tarde em Ânforas, Olência...

Água sinistra e azul ofelizada em Lua!"

(“O amor no irreal”, 1916)

"Carne-Alada d'Além cheia d'Anseio

Ida-Sombra esvaída no Desejo

e na Teia da Lenda em que me enleio"

("Síbaris", 1914)

“o Silêncio! Dum Tom maresiado

gela-se agonizante a luz no Ar"

("Lâmpada dormente", s/data)

A nova edição nos revela ainda outros avulsos, nos capítulos IV e V. Mantém-se o quadro. Versos experimentais pós-simbolistas infiltrando-se em meio às fómulas do simbolismo convencional: 
"A sombra é Deus - penumbra d'Ópio ascensa!"”

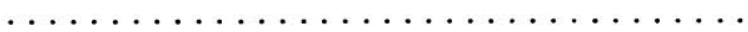

é monges d'água errante de nascente

sonhando com carenas em paisagem!"

("Crepúsculo", 1912)

“qual lume dolores diáfano e absono,"(13)

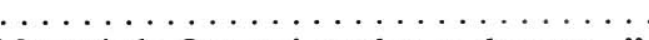

Memoriado Outono! quedou-se de neve..."

(“Lilases, violetas, memórias do outono...", 1913)

"Teu corpo para mim velou-se a véus

de rosa languidez, a lises d'alma,"

("Uma noute morria de saudade", 1915)

(Sá-Carneiro: “Humilhações a lis, desforços de brocado;”, em “'Taciturno”, 1914).

"Vi mundos atravếs dum sonho ido,

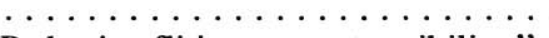

Pedraria aflitiva em rastro sibilino"

(“Excêntrico singrar”, 1916)

"Rei exilei-me em teu ruivo cismar!"

("Noite egípcia", 1915)

(radicalização do verso “- Ao meu redor eu sou Rei exilado," de “Distante melodia”, 1914).

"Visão leda do sol à cor extinta...

Ausente-Me! É a tu'alma o meu jazigo,

erro no oiro astral que tarde pinta!"

(“Carta pr'além túmulo”, 1916)

O exemplário oferecido é - ao meu ver - mais do que significativo. Em que pese a precariedade de muitos desses avulsos - rascunhos talvez não definitivos, muitos deles - já que se notam, com relativa freqüência, falseios de métrica, incompletudes frásicas ou carências de pontuação, a altitude desses versos nos surpreende e comove. Precárias, de resto, são as próprias "edições" feitas em vida do poeta - não mais do que folhas pobremente impressas e com muitos erros tipográficos. Tudo faz crer que Ernani Rosas, boêmio e inadaptado à vida prática, não desfrutava de condições econômicas muito favoráveis. É o que parecem corroborar os dados que a nova edição acrescenta à sua parca biografia.

Se a linguagem de Ernani Rosas tem a sua individualidade até certo ponto afetada pela porosidade que oferece a outros estilos - e nisso ele difere de Pedro Kilkerry, dono de um idioleto mais pronunciado -, essa circunstância não chega a tolher-lhe a invenção, patente na reelaboração crítica e seletiva que leva o poeta a soluções extraordinárias e a configuraçōes lingüísticas inteiramente estranhas à tradição e ao contexto brasileiros.

No soneto "Para que, alma, o esforço", que, segundo Muricy, lhe foi ditado pelo autor, aparece o compósito "inter-azul-sonhar":

"para que esse teu tantalizar

do sonho, em louvor de quem não sabe

medir a altura imensa que nos cabe

para adejar no inter-azul-sonhar..."

Em Sá-Carneiro encontramos por duas vezes a expressão “inter-sonho”: no título de um poema de 1912, do volume Dispersão, e no verso "Idade acorde de Inter-sonho e Lua", de “Distante melodia", 1914 (Indtcios de oiro). Quem sabe se o insólito acréscimo com que Ernani Rosas recompôs o composto, ao introjetar-lhe aquele "azul” que o erige em

13 Notar, nestes versos, o emprego de palavras raras: "ábsono" (dissonante), com acento deslocado para a paroxitona a fim de rimar com "outono"; "ascens" (de "ascender"), utilizada como adjetivo, associada ao substantivo "ascenso", termo de astronomia indicando a ascensão de um astro. 
colagem tmética e cria a diferença qualitativa - novo no novo - possa sinalizar a sensibilidade crítica com que o nosso poeta recepcionou os avanços da poesia portuguesa de Orfeu. Um mérito que não é desprezível no quadro do diluente pós-simbolismo brasileiro.

Com semelhante criatividade Gregório de Matos soube ler e apropriar o barroco espanhol. Assim, no "Epigrama”, primariamente impugnado por Snfvio Julio como plágio de Quevedo (quadras iniciais do rimance "Refiere él mismo sus defectos em bocas de otros"):

\author{
Quevedo \\ "Muchos dicen mal de mí, \\ y yo digo mal de muchos: \\ mi decir es más valiente, \\ por ser tantos y ser uno. \\ Que todos digan verdad, \\ por imposible lo juzgo; \\ que yo la diga de todos, \\ con mi licencia lo dudo. \\ Por eso no los condeno, \\ por eso no me disculpo; \\ no faltara quien nos crea \\ a los otros y a los unos." \\ Gregorio \\ “Querem-me aqui todos mal, \\ mas eu quero mal a todos, \\ eles, e eu por nossos modos \\ nos pagamos tal por qual: \\ e querendo eu mal a quantos \\ me têm ódio tão veemente \\ o meu ódio é mais valente, \\ pois sou só, e eles são tantos."(14)
}

Uma leitura não preconcebida dos textos em questão registra, desde logo, o desvio criativo com que Gregório glosou os versos de Quevedo, modificando-os e dando-lhes outra dimensão semântica e poética. O "dizer mal" de "muitos" polariza-se no "querer mal" de "todos". A indiferença risonha entre a verdade ou a mentira do "dizer" converte-se em " $\delta$ dio veemente". A própria divergência de intensificação sonora entre as rimas - consoantes em Gregório, quando eram apenas toantes em Quevedo - contribui para a maior tonicidade e dramaticidade do texto do baiano que, além de condensar e reordenar as quadras quevedianas, extrai a sátira da pauta ligeira dos jogos de espírito para projetá-la, em cheio, no âmbito dos conflitos existenciais e contextuais, potencializados ao máximo: um contra todos. "Que me quer o Brasil que me persegue?", desafiaria, em outro passo, o poeta, como que prefigurando o desentendimento secular - que até hoje subsiste - entre a sua obra e o presunçoso menosprezo dos marinícolas literários de todos os tempos, "os néscios que motejam"...

Contrariamente ao que imaginam certas mentes redutoras e mesquinhas da nossa crítica comparatista, por vezes alambicadas de eruditismos, mas notoriamente incompetentes para aferir valores artísticos, nem sempre a influência desqualifica a criatividade e a invenção. Estas também se explicitam na capacidade de discernir a informação renovadora, no saber assimilar e dominar as linguagens de transformação de uma época. "To gather from the air a live tradition". $\mathrm{O}$ "paideuma" poundiano. "Transformar o tabu em totem". Antropofagia: de Quevedo e Gôngora por Gregório; de Steme por Machado; de Cendrars por Oswald. Por mais que assuste aos papiloscopistas de plantão da nossa subcrítica acadêmica, a metáfora antropológica oswaldiana se ajusta como luva à situação da literatura brasileira, tanto na sua mais inteligente recepção quanto nas suas mais sensíveis rupturas com as matrizes européias, de onde proveio. Antropofagia, insisto (e só mesmo um néscio cobraria precisão cronológica à metáfora). Ter o faro do tempo, reconhecer o novo, injetá-lo na circulação sangüínea do corpo contextual, e ser capaz de renová-lo. 